\title{
THE ROLE OF MAP KINASES IN IMMUNE RESPONSE
}

\author{
Malgorzata KRZYZOWSKA, Weronika SWIATEK, Beata FIJALKOWSKA, \\ Marek NIEMIALTOWSKI, Ada SCHOLLENBERGER \\ Division of Immunology, Department of Pre-clinical Sciences, Faculty of \\ Veterinary Medicine, Warsaw University of Life Sciences
}

DOI: $10.2478 / \mathrm{v} 10052-010-0007-5$

\begin{abstract}
Summary: The MAP kinases (MAPKs), including ERK, JNK and p38 families comprise part of the intracellular signalling network, which is essential for signal transduction from receptors and stimuli to the biological reaction. Activity of MAPKs plays a crucial role in normal functioning of the immune system. By taking part in cytokine production upon signalling from activated TLR receptors, MAPKs are involved in initiation of innate immunity and in responses to binding of cytokines by appropriate receptors. MAPKs activity is also important for T and B lymphocyte differentiation, by the ITAM signalling pathway. Moreover, their involvement in apoptosis supports lymphocyte T cytotoxicity and enables the removal of damaged, infected or transformed cells. Correct functioning of the MAPK signalling is crucial for effective immune response, and therefore MAPKs' inhibitors constitute a promising therapeutic goal.
\end{abstract}

Key words: MAP kinases, ERK, JNK, p38

\section{MAP KINASES}

Intracellular signal transduction allows cells to respond to signals from the extracellular environment, detected by appropriate receptors. This response involves changes in genes expression and cell functioning [41].

MAP kinases (mitogen activated protein kinases, MAPK) are serine/threonine kinases activated by mitogens, which were first described as the proteins activated by growth factors [26]. All the MAPKs posses a Thr-X-Tyr (TXY) motif within their activation loop. Three main families of MAPKs exist in mammalian species: ERK (extracellular signal-regulated kinase), containing Thr-Glu-Tyr (TEY) motif, JNK/SAPK (c-Jun N-terminal/stress-activated protein kinase) containing Thr-ProTyr motif (TPY) and p38 kinase, with Thr-Gly-Tyr motif (TGY) [26]. 
MAPKs are activated through a triple phosphorylation cascade: MAP kinase kinases (MAPKKs or MAP2Ks) phosphorylate MAPK on Thr and Tyr, while MAPKKs are activated after phosphorylation on their Ser/Thr residues by MAP kinase kinase kinases (MAPKKKs or MAP3K). Adaptor proteins, such as Grb2, Sos or Vav are also necessary for transduction of the signal from the activated receptors to MAPKs [26] (Fig.1).

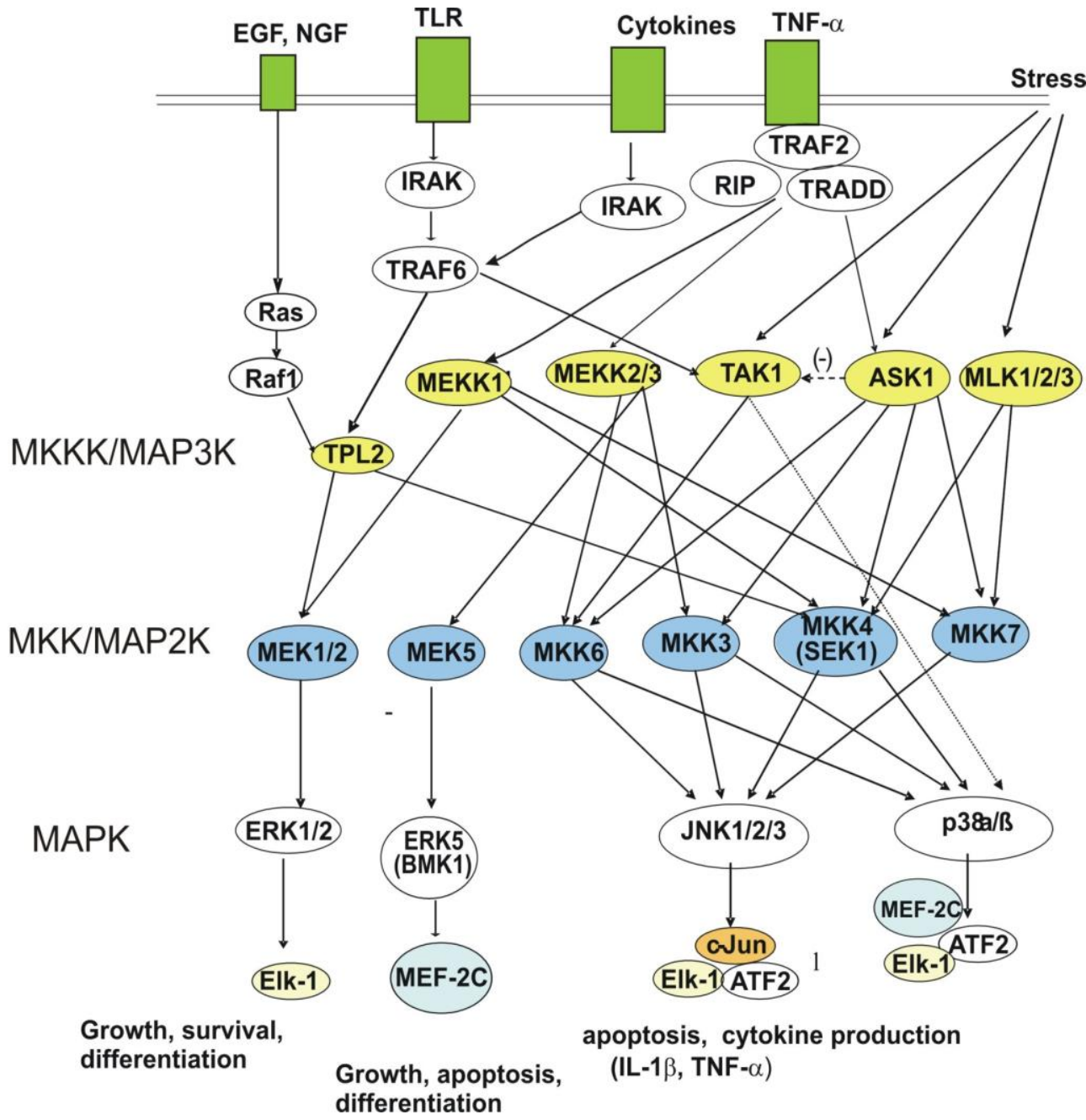

FIGURE 1. Signalling cascades if MAP kinases. Activation of MAP kinase signalling pathways is based upon a triple cascade. MAP kinases are activated by MAP kinase kinases - MKK/MAP2K, including: MEK 1/2, MKK3, MKK4 (SEK 1) MEK 5, MKK6 and MKK7. MAP2 kinases are activated by MAP kinase kinase kinases - MKKK/MAP3K. To date, 14 MKKK have been identified, including: TPL2, MEKKK1/2/3, TAK1, ASK1, MLK1/2/3. MKKKs are regulated by multiply transduction pathways upstream (TLRs, cytokine receptors and growth factors). 
ERK kinase cascade was the first described protein cascade. This kinase has two homologous forms: ERK1 (p44) and ERK2 (p42), with the basic Raf/MEK/ERK cascade. ERK signalling pathways are activated by various growth factors and they induce transition from the quiescent state into the cell cycle. ERKs are also involved in cell proliferation, migration and differentiation. Their activity leads to activation of transcription factors, such as: Elk1, c-Myc, c-Fos or STAT3 [40] (Fig.1). The family of ERK kinases is divided into two groups: 1) classic MAP kinases with ERK1 and ERK2 2) and large MAP kinases, such as ERK3, ERK5, ERK7 and ERK8, which contain an additional C-end domain [1, 40, 52].

JNK signalling pathway is recruited by stress factors, cytokines and some growth factors. JNK stress pathways participate in many different intracellular processes, including cell response to stress and apoptosis [27, 67]. JNKs are directly activated by the phosphorylation catalysed by the dual-specificity kinases MKK4 and MKK7, and their substrates are c-Jun and ATF2 transcription factors and proteins from Bcl-2 family. There are three isoforms of JNKs: ubiquitous JNK1 and JNK2 isoforms and JNK3, present only in the brain [2] (Fig.1).

Another signalling MAP kinase pathway activated in stress and by cytokines is the p38 signalling pathway. At least four isoforms of p38-MAPK are known: $\alpha, \beta$, $\gamma$ and $\delta$ MKK3 and 6 are direct activators of p38, and this pathway leads to phosphorylation of ATF2, NF- $\kappa$ B or MK2 [26, 67].

Many proteins are the substrates of MAP kinases, including transcription factors such as: ATF2 (activating transcription factor 2), Elk-1, Fos, Jun, MEF2 (myocyte enhancer factor 2), Myc and other protein kinases [26, 41]. Within a short span of time, the cell receives different signals which induce different, sometimes contradictory effects. Therefore, the signalling pathways inside the cell cooperate and influence each other in a so called cross-talk [26,41], which allows for integration of all external signals and definition of the cellular answer. Frequent interactions are observed between MAPKs and tyrosine kinases (Src), phospholipase C (PLC) or the NF- $\kappa B$ pathway [26].

Activation of MAP kinases, its length and intensity, are necessary for regulation of the immune response. Negative regulation of MAPKs activity is possible due to MAP kinase phosphatases - MKP, catalysing de-phosphorylation of tyrosine and threonine in the Thr-X-Tyr motif [7]. So far, 13 MKPs with different substrate specificities, intracellular localisation and action have been identified [20]. 


\section{INNATE IMMUNE MECHANISMS}

\section{Toll-like receptors (TLR)}

The innate immunity system detects the presence and nature of infection, provides the first line of host defence and controls initiation and determination of the effector class of the adaptive immune response. Multicellular organisms can recognise defined, conserved molecular patterns of microorganisms by Toll-like receptors (TLRs) [12]. Eleven TLRs have been described so far and each TLR recognises specific molecular patterns of microorganisms. For example, TLR2 recognises lipoteichoic acids and peptidoglycans [19], TLR4 binds LPS [19], and TLR3 recognises viral dsRNA [30], while TLR9 recognises bacterial DNA rich in $\mathrm{CpG}$ sequences [54]. A pathogen's recognition by TLRs induces signal transduction leading to activation of the transciption factor NF-kB and MAP kinases such as p38 and JNK. This activation leads to production of multiple cytokines (TNF- $\alpha$, IL-1, IL-6 and IL-12), adhesion molecules, and ultimately leads to inflammatory processes $[60,62,63]$.

Activation of TLR4 or TLR2 requires interaction of its cytoplasmic domain TIR with adaptor protein MyD88 (myeloid differentiation factor 88), which in turn interacts with IRAK kinases (interleukin-1 receptor-associated kinase) [44]. Activated by autophosphorylation, IRAK kinases activate TRAF6 protein, and downstream kinases, such as JNK and p38 are activated [10, 63]. This pathway is activated in macrophages upon binding of Mycobacterium sp. by TLR2 [61]. Macrophages stimulated by LAM (lipoarabinomannan) from mycobacterial cell walls showed significant activation of ERK and p38, resulting in TNF- $\alpha$ synthesis [28]. The authors also showed that ERK activity, induced by MEK-1, is necessary for production of TNF- $\alpha$ during Mycobacterium avium infection [28].

The signal transduction pathway activated upon binding of viral dsRNA to TLR3 receptors on NK cells is different [49]. In this process, TRIF/TICAM-1 (TIR-containing adapter molecule-1) adaptor complex is bound to the TIR domain of the activated TLR3 receptor, forming an active enzymatic complex inducing the cascade leading to activation of p38 kinase and transcription of cytokines and chemokines, such as IFN- $\gamma$, CXCL-10 and 8 [49].

Three signalling modules are involved in TNF- $\alpha$ and IL-1 production upon virus infection of epithelial cells in the respiratory system [37]. Expression of these cytokines requires activation of PKR kinase. The effectors of p38 kinase are transcription factors: Mef-2, Elk-1 and ATF-2, modulating expression of IL-1 and TNF- $\alpha$ genes. Meusel and Imani [37] showed that the type of cytokines produced depends on the activation of the particular p38 kinase isomer $-\alpha, \beta, \gamma$ or $\delta$. Other authors have demonstrated recently that specific cell types of the immune system show activity of particular isoforms of p38 kinase, which determines the type of cytokines produced upon TLR stimulation in the given cells [2, 27]. 
Additionally, the p38 kinase cascade regulates TNF- $\alpha$ production at posttrascriptional level [4]. mRNA for this protein has the ARE (AU rich elements) sequence at its 3' position in the form of repeats (AUUUA)n. If there is no stimulation, this sequence enables mRNA destabilisation and its destruction, and inhibits its protein translation. Multiple research groups confirmed the influence of p38 kinase cascade upon stabilisation of transcripts containing ARE sequences $[4,17,34]$. Hitti et al. showed that p38 stabilises mRNA for TNF- $\alpha$ by activation of MK2 kinase, which phosphorylates tristetraproline protein (TTP) and by binding to the RNA in the ARE region, influences fast mRNA destabilisation and TTP, phosphorylated by MK2, loses its ability to bind to mRNA [17]. Interferon $\gamma$ transcripts also possess ARE sequences. It has been shown that after using p38 kinase inhibitor SB203580 in NK cells stimulated with IL-12 and 18, the level of IFN- $\gamma$ significantly decreases [34].

\section{MAP kinases in response to cytokines}

Also by the means of MAP kinases, signals induced by cytokines are transduced from their receptors in the cell membrane, resulting in specific effects. Two receptors of TNF- $\alpha$ are known: TNFR1 (p55) and TNFR2 (p75). TNFR1 has an intracellular death domain (DD) which can bind different adaptor proteins [48] and, depending on the type of adaptors, apoptotic or survival cell pathways are induced. If TNFR1 binds the adaptor protein TRADD (TNFR associated death domain-containing protein) and other adaptor proteins, such as those from the TRAF family (TNFR associated factor) or RIP kinase (receptor-interacting protein), JNKs and p38 as well as NF-kB are activated [4, 13, 14, 31]. Lee et al. showed that RIP kinase and TRAF2 factor regulate JNK and p38 kinases independently [4]. RIP kinase is necessary to activate the p38 kinase cascade and it interacts directly with MEKK3. It also regulates the process of IKK activation, responsible for formation of the active form of NF- $\mathrm{BB}$ [4]. RIP-dependent activation of $\mathrm{p} 38$ kinase and NF- $\mathrm{KB}$ is necessary for production of IL-6 induced by TNF- $\alpha$. [4, 13]. Additionally, RIP kinase leads to ERK activation [32].

Similar signalling pathways are activated as a result of the stimulating influence of IL-1. Receptors for this cytokine, similar to TLRs, possess a cytoplasmatic TIR domain. The active complex ligand-receptor results in binding of adaptor MyD88 protein and activation of TRAF6 factor by IRAK kinases [44]. The role of MAPKKK is played by TAK-1 protein, which forms a functional complex with TAB-1 and TAB-2 proteins (TAK binding protein) and it is directly activated by TRAF6 [22]. MKK7 activates JNK, while MKK3 and 6 activate p38. Additionally, TAK-1 also participates in activation of NF- $\kappa B$, by phosphorylating NIK kinase, which in turn activates IKK kinase [58]. The above described transduction pathways result in active transcription factors NF- $\mathrm{KB}, \mathrm{AP}-1$ or ATF-2, and the biological response of the cells to the given signal. 


\section{ADAPTIVE IMMUNE RESPONSES}

\section{Activation of $\mathbf{T}$ lymphocytes}

MAPKs cascades play an important role in the process of lymphocyte proliferation and differentiation and MAPKs activity is of a key importance for thymocyte maturation. The thymocytes, which properly recognise antigens in the context of MHC, differentiate into $\mathrm{CD} 8^{+}$or $\mathrm{CD} 4^{+} \mathrm{T}$ cells. ERK activity is required for this process and it is inhibited by ERK inhibitors [36]. McNell et al. showed that positive selection takes place during a long-term activation of ERK kinase, probably ERK kinase prevents thymocyte apoptosis by phosphorylation of proapoptotic Bim [36]. On the other hand lymphocytes, which recognise own antigens, are subjected to negative selection and undergo apoptosis. JNK and p38 are involved in this process after activation by MINK (ASK2/MAPKKK6) kinase [18].

Mature T lymphocytes, which possess TCR receptors (T-cell receptor) on their surface, are responsible for recognition of an antigen. A lymphocyte requires two signals to become activated. The first signal is delivered by TCR receptors which recognise the antigen, while the second signal, a so called co-stimulatory signal, is delivered by interaction of different adhesion factors on the surface of $\mathrm{T}$ lymphocytes (CD28 or CTLA-4) with the accessory receptors localised on the surface of antigen presenting cells (APC) (Fig. 2). Lacking the second signal, lymphocytes lose their ability to become activated and become anergised. Both TCR receptors, as well as CD3 glycoproteins possess cytoplasmic ITAM domains (immunoreceptor tyrosine-based activation motif) [8, 13, 57]. Binding of an antigen by TCR-CD3 complex induces intercellular signalling pathways. ITAM domains have no autocatalytic properties but they are activated by non-receptor tyrosine kinases from the Src family (Lck, Fyn), the latter kinases being bound to cytoplasmic domains of CD4+ or CD8+ receptors. As a result of binding external domains to the appropriate MHC molecules presenting antigens, dissociation and migration of Src kinases takes place and the two tyrosines within the characteristic motif of ITAM domains become phosphorylated. Activated ITAMs bind kinases from the Syk family (Syk and ZAP-70) and become further phosphorylated [12, 20, 57].

Activated Syk kinases phosphorylate adaptor proteins. LAT (p36) is one of the best known adaptor proteins activated by Syk kinases in T cells [21] and it is critical for transduction of cellular signals. LAT protein can bind other adaptors or enzymatic proteins, resulting in different effects. MAPKs play an important role in this process. The phosphorylated LAT protein binds Grb2 protein, and the Ras/Raf/MEK/ERK cascade is activated, resulting in the recruitment of AP-1 factor involved in T lymphocytes activation [32].

ERK cascade can be activated independently from Grb2 by protein kinase $\mathrm{C}$. Upon binding of phospholipase $\mathrm{C}$ to LAT, secondary mediators $\mathrm{IP}_{3}$ and DAG are produced [6]. DAG in turn activates PKC, which stimulates ERK cascade at the 


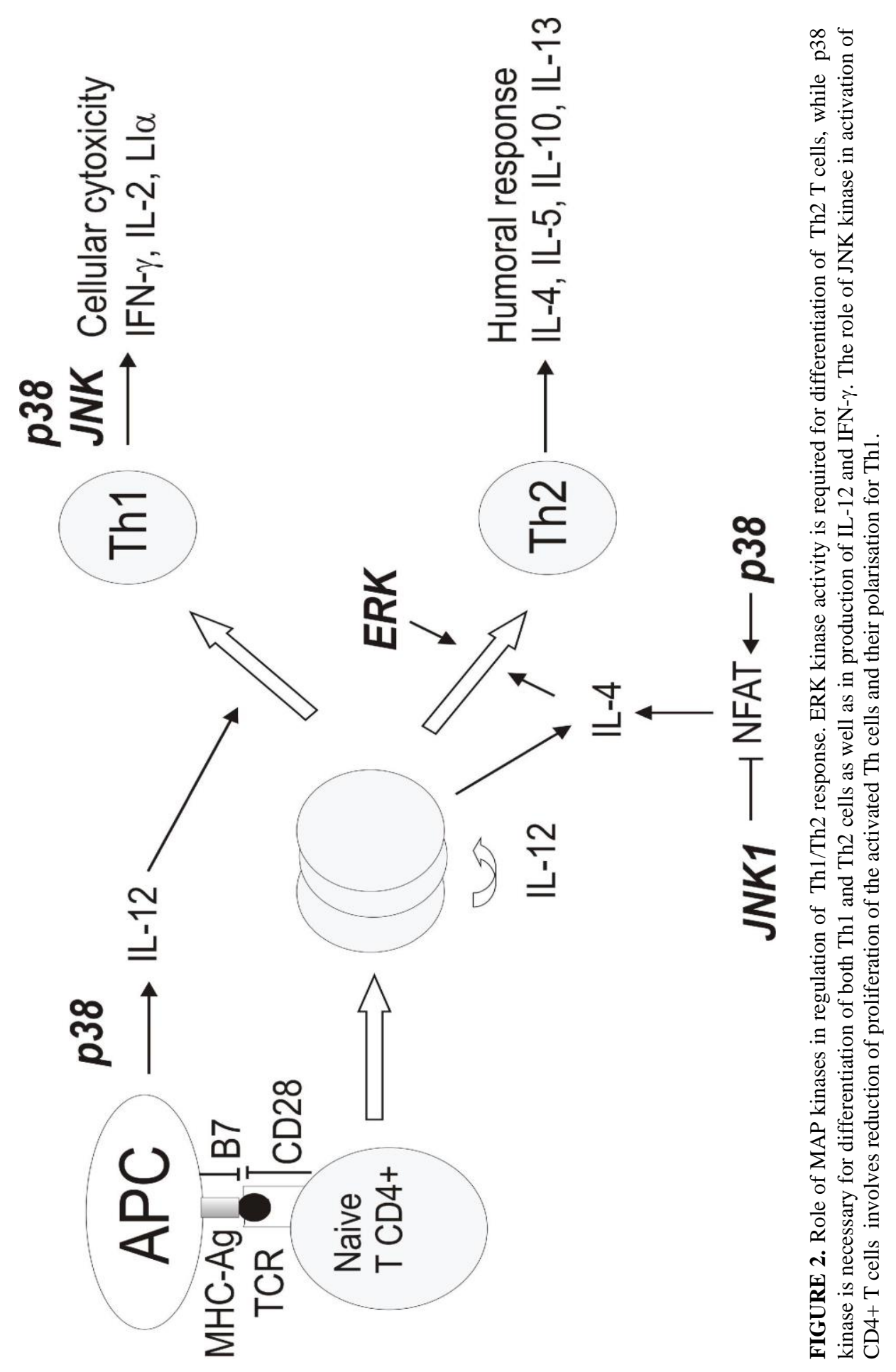


level of Ras protein [51, 68]. Directed by transcription factors, activity of the ERK pathway determines differentiation of Th2 lymphocytes.

Recruitment of an adaptor protein Vav to TCR leads to activation of JNK [24] and to down-stream activation of c-Jun, present in AP-1, and to activation of NAFTc2 [43]. Binding of these two factors within the promoter of IL-2 enables its expression. Several studies have shown that other signalling pathways of MAPKs are also involved in regulation of NFATs activity [4, 64].

The classic activation of $\mathrm{p} 38$ kinases takes place in Th1 $\mathrm{T}$ cells upon stimulation with IL-12 and IL-18 for IFN- $\gamma$ production [2, 3] (Fig.2), although Mittelstadt et al. also showed the existence of an alternative p38 activation pathway in T cells through TCR receptors [38]. The alternative pathway operates without involvement of the LAT protein and MAPKKs or MAPKKKs. A receptor-derived signal leads to activation of tyrosine kinase Lck, and this kinase in turn activates ZAP-70 kinase, directly responsible for activation of p38 kinase at tyrosine 323, while the classic activation of p38 takes place at both Thr 180 and Tyr 182. The p38 kinase with phosphorylated Tyr 323 shows autocatalytic properties and conducts the double phosphorylation of the classic motif, leading to its active form [56]. Alternative activation of p38 kinase can be blocked by Gadd $45 \alpha$ suppressor protein which, upon direct interaction with p38 kinase, enables its phosphorylation blocks autocatalysis [55].

The mechanism of alternative activation of $\mathrm{p} 38$ kinase was observed only in $\mathrm{T}$ cells and it is possible that this pathway may lead to T cell anergy [38]. OhkusuTsukada et al. showed that anergy of $\mathrm{CD}^{+} \mathrm{T}$ cells is induced by inhibition of ERK pathway by p38 kinase cascade activated by TAK-1 [42]. Anergy can also take place as a result of improper signalling via PKC/Ras/Raf/MEK/ERK cascade or disturbances in Ras protein activity [42].

MAP kinases play an important role in activation, differentiation and functioning of CD4+ and CD8+ T cells (Fig.2). On the basis of cytokines produced and their immunostimulatory effect, two classes of Th cells are distinguished: Th1 and Th2. Th1 cells produce INF- $\gamma$ and lymphotoxin- $\alpha$, which stimulate the cytotoxic response, while Th2 cells produce IL-4, IL-5, IL-9, IL-10, which are involved in activation and differentiation of B cells. The Ras/ERK pathway plays a role in differentiation of Th2. ERK plays an important role in IL-2 expression during TCR-induced differentiation of CD4+ Th2 cells [22,50]. By using an inhibitor of p38 kinase, SB 203580, it was shown that this kinase is required for IL-2 production, both in mature (spleen) and in immature (thymus) $\mathrm{T}$ cells [4]. Additionally, p38 kinase cascade is important for differentiation of Th1 cells and development of cytotoxicity (Fig.2) [3,62] and it is necessary for production of many cytokines by inducing IL-12 production in Th1 cells and by inducing IFN- $\gamma$ production both in Th1 and Tc cells [50]. JNK kinase is involved in activation of T cells and its role involves reduction of the proliferative response of the activated Th cells and strengthening of Th polarisation towards Th1 [59]. 


\section{Activation of $B$ cells}

The cytoplasmic membrane of B cells possesses immunoglobulin receptors, called BCRs ( $B$ cell receptor). Their intracellular part consists of a heterodimer of $\operatorname{Ig} \alpha(\mathrm{CD} 79 \mathrm{a})$ and $\operatorname{Ig} \beta$ (CD79b), each containing 1 ITAM domain [12]. As in the case of TCR, phosphorylation of ITAM domains involves Src kinases and activation of Syk kinases induces intracellular transduction pathways [16, 17, 29]. BCR receptors initiate PI-3K, Ras and phospholipase C pathways [11, 29], and their interactions result in lymphocyte proliferation and humoral response to antigen.

In response to BCR stimulation in the process of $\mathrm{B}$ cell activation and proliferation, the ERK kinase pathway plays the most important role. It can be activated by Raf/MEK/ERK or the PI-3K kinase cascade $[15,29,46]$. During B cell proliferation, ERK kinase regulates activity of cyclin D, allowing for a cell transition from the G1 phase to S phase [46, 47].

Activity of p38 $\alpha$ kinase is related mostly with production of $\operatorname{IgE}$ by CD40stimulated $\mathrm{B}$ cells, and it results from induction of NF- $\mathrm{KB}$ transcription factor. The activity of p38 kinase in this process is regulated by Lyn and Syk kinases $[29,66]$.

\section{APOPTOSIS}

Apoptosis, or programmed cell death, is a mechanism responsible for proper functioning of the immune system. It is involved in differentiation of T cells and B cells, immune suppression, it enables destruction of intracellular pathogens and elimination of defective, destroyed or transformed cells. Apoptosis can be induced by cytokines produced by the immune cells, such as TNF- $\alpha$ or IL-1, reactive oxygen species (ROS), binding of Fas ligand by the infected cells or by a direct interaction of a pathogen with cells bearing Fas receptor. Apoptosis can be induced through two processes: 1) extracellular receptor pathway, when apoptosis is induced by activation of receptors containing death domain (DD) $[2,4,33]$, and intracellular pathway caused by mitochondrial destruction and activity of proteins from the Bcl-2 family [5, 53]. Ultimately, both processes lead to activation of caspases and proteolytic degradation of cellular structures. MAPKs play a significant role in regulation of apoptosis and JNK and p38 kinases are responsible for apoptosis induction, while ERK kinases posses anti-apoptotic activities [60, 62].

A model cytokine inducing apoptosis is tumour necrosis factor $\alpha(\mathrm{TNF}-\alpha)$. Binding of the ligand to TNFR1 possessing intracytoplasmic death domain (DD) initiates a reaction. Association of adaptor proteins TRADD and TRAF2 with the DD within the receptor leads to activation of a key MAPK kinase 292 for the apoptotic process - ASK-1. Activation of ASK-1 requires the presence of reactive oxygen species $[9,39]$. Inactive ASK-1 creates a complex with tioredoxin (Trx), 
consisting an oxidative stress sensor in the cells. Only after TNF- $\alpha$, or other factors causing oxidative stress, start to act, is Trx oxidised and the complex degrades while a free form of ASK-1 activates MKK4/7 and MKK3/6, which in turn phosphorylate JNK and p38, respectively [35]. Transcription factors are activated, mainly ATF-2 and c-Jun, which create the AP-1 complex, ultimately leading to expression of pro-apoptotic genes [35].

Apoptosis is a key process for proper development of $\mathrm{T}$ cells in the thymus and this process is regulated by MAPKs. The cytotoxic effect of CD8+ T cells is executed by the release of cytolytic granules or by interaction between membrane proteins of the CD8 lymphocyte and the target cell. Apoptosis is one of the cytotoxcity mechanisms of CD8+ T cells and it is based upon interaction of FasL molecules present on $\mathrm{T}$ cells with the Fas receptor (Apo1, CD95) present on the infected cell. These receptors possess a death domain in their cytoplasm which allows for induction of apoptosis upon the ligand binding. The classic pathway leads through binding of FADD to activation of caspase-8, but activation of Fas receptors may also lead to induction of the JNK cascade. Such a situation arises when active Fas receptors bind to another adaptor protein, Daxx. In this way, activated Daxx protein binds with ASK-1 and activates it [25]. The mechanism responsible for activation of MAPK in response to FasL binding supports the main caspase-8-dependent apoptotic pathway. However, this is not a key apoptotic pathway, as shown by Matsuzawe et al - FasL-induced apoptosis can take place without the presence of ASK-1 [9]. In contrast to apoptosis induced by TNF- $\alpha$, activation of ASK-1 does not require concurrent oxidative stress [9]. Expression of FasL proteins is observed mainly on CD8+, CD4+T cells and on NK cells.

\section{SUMMARY}

MAPKs cascades are very important intracellular transduction pathways responsible for normal development and maintenance of the immune system. They play an important role in the first steps of infection, are responsible for production of the cytokines such as TNF- $\alpha$, IL- 1 or IFN- $\gamma$ upon TLRs stimulation. They are responsible not only for induction of cytokine synthesis, but they also participate in the pathways induced by these cytokines. MAPKs play a key role in differentiation and maturation of $\mathrm{T}$ cells in the thymus, they are involved in activation of $\mathrm{T}$ cells and $\mathrm{B}$ cells and in directing the immune response in the Th-1 or Th-2-dependent pathway.

The critical role of MAPKs cascades during the course of the immune response indicates that these enzymes may provide an alternative to anti-viral, anti-bacterial, anti-inflammatory and anti-tumour drugs - inhibitors of JNK p38 are tested as potential drugs in therapy of pathological states, such as rheumatoid arthritis $[23,65]$. 


\section{REFERENCES}

[1] ABE MK, SAELZLER MP, ESPINOSA R III, KAHLE KT, HERHENSON MB, LE BEAU MM, ROSNER MR. ERK8, a new member of the mitogen-activated protein kinase family. J Biol Chem 2002; 277: 16733-16743.

[2] ASHWELL JD. The many pathways to p38 mitogen-activated prtein kinase activation In the immune system. Nat Rev Immunol 2006; 6: 532-540.

[3] BERENSON LS, YANG J, SLECKMAN BP, MURPHY TL, MURPHY KM. Selective requirement of p38\{alpha\} MAPK in cytokine-dependent, but not antigen receptor-dependent, Th1 responses. J Immunol 2006; 176: 4616-4621.

[4] COOK R, WU CC, KANG YJ, HAN J. The role of the p38 pathway in adaptive immunity. Cell Mol Immunol 2007; 4: 253-259.

[5] CZARNECKA AM, GOLIK P, BARTNIK E. Mitochondria jako integratory apoptozy. Post Biol Kom 2006; 33: 525-542.

[6] DIAZ-FLORES E, SILICEO M, MARTINEZ AC, MERIDA I. Membrane translocation of protein kinase $\mathrm{C}$-theta during $\mathrm{T}$ lymphocyte activation requires phospholipase $\mathrm{C}$-gamma-generated diacylglycerol. J Biol Chem 2003; 278: 29208-29215.

[7] DICKINSON RJ, KEYSE SM. Diverse physiological functions for dual-specificitity. MAP kinase phosphatases. J Cell Sci 2006; 119: 4607-4615.

[8] DUSTIN ML. T-cell activation through immunological synapses and kinapses. Immunol Rev 2008; 221: 77-89.

[9] FUJISAWA T, TAKEDA K, ICHIJO H. ASK family proteins in stress response and disease. Mol Biotechnol 2007; 37: 13-18.

[10] GOHDA J, MATSUMURA T, INOUE J. Cutting edge: TNFR-associated factor (TRAF) 6 is essential for MyD88-dependent pathway but not toll/IL-1 receptor domain-containing adaptor-inducing IFNbeta (TRIF)-dependent pathway in TLR signaling. J Immunol 2004; 173: 2913-2917.

[11] GOLD MR. B cell development: important work for ERK. Immunity 2008; 28: 488-490.

[12] GOŁĄB J, JAKÓBISIAK M, LASEK W, STOKŁOSA T. Immunologia. Wyd. Nauk PWN, Warszawa, 2008.

[13] GORTZ B, HAYER S, TUERCK B, ZWERINA J, SMOLEN JS, SCHETT G. Tumour necrosis factor activates the mitogen-activated protein kinases $\mathrm{p} 38 \alpha$ and ERK in the synovial membrane in vivo. Arthritis Res Ther 2005; 7: R1140-R1147.

[14] HABELHAH $\mathrm{H}$, TAKAHASHI $\mathrm{S}$, CHO SG, KADOYA T, WATANABE $\mathrm{T}$, RONAI $Z$ Ubiquitination and translocation of TRAF2is required for activation of JNK but not of p38or NF-kB. EMBO J 2004; 23: 322-332.

[15] HAN A, SAIJO K, MECKLENBRAUKER I, TARAKHOVSKY A, NUSSENZWEIG MC. Bam32 links the $B$ cell receptor to ERK and JNK and is essential for B cell proliferation but not survival. Immunity 2003; 19: 621-634.

[16] HERRIN BR, JUSTEMENT LB. Expression of the adaptor protein hematopoietic Src homology 2 is up-regulated in response to stimuli that promote survival and differentiation of B cells. J Immunol 2006; 176: 4163-4172.

[17] HITTI E, IAKOVLEVA T, BROOK M, DEPPENMEIER S, GRUBER AD, RADZIOCH D, CLARK AD, BLACKSHEAR PJ, KOTLYAROV A, GAESTEL M. Mitogen-activated protein kinaseactivated protein kinase 2 regulates tumor necrosis factor mRNA stability and translation mainly by altering tristetraprolin expression, stability, and binding to adenine/uridine-rich element. Moll Cell Biol 2006; 26: 2399-2407.

[18] HSU S, WU C, HAN J, LAI M. Involvement of p38 mitogen-activated protein kinase in different stages of thymocyte development. Blood 2003; 101: 970- 976

[19] JACINTO R, HARTUNG T, MCCALL C, LI L. Lipopolysaccharide- and lipoteichoic acid-induced tolerance and cross-tolerance: distinct alterations in IL-1 receptor-associated kinase. J Immunol 2002; 168: 6136-6141.

[20] JEFFREY KL, CAMPS M, ROMMEL C, MACKAY CR. Targeting dual-specificity phosphatases: manipulating MAP kinase signalling and immune responses. Nat Rev Drug Discov. 2007; 6: 391-403. 
[21] JIANG Y, CHENG H. Evidence of LAT as a dual substrate for Lck and Syk in T lymphocytes.Leuk Res 2007; 31: 541-545.

[22] JORRITSMA PJ, BROGDON JL, BOTTOMLY K. Role of TCR-induced extracellular signalregulated kinase activation in the regulation of early IL-4 expression in naïve CD4+ T cells. $J$ Immunol 2003; 170: 2427-2434.

[23] KAMINSKA B. MAPK signalling pathways as molecular targets for anti- inflammatory therapy- from molecular mechanisms to therapeutic benefits. BBA Biochem Biophys Acta 2005; 1754: 253-262.

[24] KATZAV S. Vav1: an oncogene that regulates specific transcriptional activation of $\mathrm{T}$ cells. Blood 2004; 7: 2443-2451.

[25] KHELIFI AF, ALCONTRES MS, SALOMONI P. Daxx-_is reg reguired for strestress-induceed celll death and JNK activation. Cell Death Differ 2005; 12: 724-733.

[26] KLEIN A. Molekularne podstawy regulacji hormonalnej. Wyd. UJ, Kraków, 2002.

[27] KORB A. TOHIDAST- AKRAD M, CETIN E, AXMANN R, SMOLEN J, SCHETT G. Differential tissue expression and activation of $\mathrm{p} 38 \mathrm{MAPK} \alpha, \beta, \gamma$ and $\delta$ isoforms in rheumatoid arthritis. Arthritis Rheum 2006; 54: 2745-2756.

[28] KOUL A, HERGET T, KLEBL B, ULLRICH A. Interplay between mycobacteria and host signalling pathways. Nat Rev Microbiol. 2004; 2: 189-202

[29] KUROSAKI T, HIKIDA M. Tyrosine kinases and their substrates in B lymphocytes. Immunol Rev 2009; 228: 132-148.

[30] LEE HK, DUNZENDORFER S, SOLDAU K, TOBIAS PS. Double-stranded RNA-mediated TLR3 activation is enhanced by CD14. Immunity 2006; $24: 153-163$.

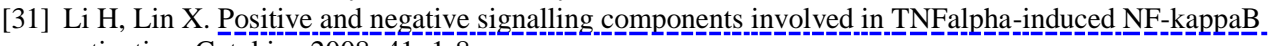
activation. Cytokine 2008; 41: 1-8.

[32] MARTELLI MP, LIN H, ZHANG W, SAMELSON LE, BIERER BE. Signaling via LAT (linker for T-cell activation) and Syk/ZAP70 is required for ERK activation and NFAT transcriptional activation following CD2 stimulation. Blood 2002; 96: 2181-2190.

[33] MARUNIEWICZ M, WOJTASZEK P. Pochodzenie i ewolucja śmierci komórki. Post Biol Kom 2007; 34: 651-667.

[34] MAVROPOULOS A, SULY G, COPE AP, CLARK AR. Stabilization of IFN- $\gamma$ mRNAby MAPK p38 in IL-12- and IL-18-stimulatedhuman NK cells. Blood. 2005; 105: 282-288.

[35] MCCUBREY JA, LAHAIR MM, FRANKLIN RA. Reactive oxygen species-induced activation of the MAP kinase signaling pathways. Antioxid Redox Signal 2006; 8: 1775- 1789.

[36] McNEIL LK, STARR TK, HOGQUIST KA. A reguirement for sustained ERK signaling during. thymocyte positive selection in vivo. Proc Natl Acad Sci U S A 2005; 102: 13574-13579.

[37] MEUSEL TR, IMANI F. Viral induction of inflammatory cytokines in human epithelial cells follows a p38 mitogen-activated protein kinase-dependent but NF-KB-independent pathway. J Immunol 2003; 171: 3768- 3774 .

[38] MITTELSTADT PR, SALVADOR JM, FORNACE AJ, ASHWELL JR. JD. Activating p38 MAPK: new tricks for an old kinase. Cell Cycle 2005; 4: 1189-1192.

[39] NAGAI H, NOGUCHI T, TAKEDA K, ICHIJO H. Pathophysiological roles of ASK1-MAP kinase signaling pathways. J Biochem Mol Biol 2006; 40: 1-6.

[40] NISHIMOTO S, NISHIDA E. MAPK signalling: ERK5 versus ERK1/2. EMBO Rep 2006; 7: 782786.

[41] NOWAK JZ, ZAWILSKA JB. Receptory i mechanizmy przekazywania sygnału. Wyd. Nauk. PWN, Warszawa, 2004.

[42] OHKUSU-TSUKADA K, TOMINAGA N, UDONO H, YUI K. Regulation of the maintenance of peripheral T-cell anergy by TAB1-mediated p38-alpha activation. Mol Cell Biol 2004; 24: 6957-6966.

[43] ORTEGA-PEREZ I, CANO E, WERE F, VILLAR M, VAZQUEZ J, REDONDO JM. c-Jun Nterminal kinase (JNK) positively regulates NFATc2 transactivation through phosphorylation within the N-terminal regulatory domain. J Biol Chem 2005; 28: 20867-20878.

[44] PAN ZK. Toll-like receptors and TLR-mediated signaling: more questions than answers. Am J Physiol Lung Cell Mol Physiol 2004; 286: L918-L920.

[45] PARK HH, LO YC, LIN SC, WANG L, YANG JK, WU H. The death domain superfamily in intracellular signalling of apoptosis and inflammation. Annu Rev Immunol 2007; 25: 561-586. 
[46] PIATELLI MJ, DOUGHTY C, CHILES TC. Requirement for a hsp90 chaperone-dependent MEK1/2ERK pathway for B cell antigen receptor-induced cyclin D2 expression in mature B lymphocytes. J Biol Chem 2002; 277: 12144-12150.

[47] PIATELLI MJ, WARDLE C, BLOIS J, DOUGHY C, SCHRAM BR, ROTHSTEIN TL, CHILES TC. Phosphatidylinositol-3-kinase-dependent MEK1/2-ERK and NF-kappaB signaling pathways are required for B cell antigen receptor-mediated cyclin D2 induction in mature B lymphocytes. J Immunol 2004; 172: 2753-2762.

[48] PIEKAROWICZ A. Podstawy wirusologii molekularnej. Wyd. Nauk. PWN, Warszawa, 2004.

[49] PISEGNA S, PIROZZI G, PICCOLI M, FRATI L, SANTONI A, PALMIREI G. p38 MAPK activation controls the TLR3-mediated up-regulation of cytotoxicity and cytokine production in human NK cells. Blood 2004; 104: 4157-4164.

[50] RINCON M, DAVIS RJ. Regulation of immune response by stress-activateded protein kinases. Immuno Rev 2009; 228: 212-214.

[51] ROOSE JP, MOLLENAUER M, GUPTA VA, STONE J, WEISS A. A diacylglycerol-protein kinase C-RasGRP1 pathway directs Ras activation upon antigen receptor stimulation of $\mathrm{T}$ cells. Mol Cell Biol 2005; 25: 4426-4441.

[52] RUBINFELD H, SEGER R. The ERK cascade: a prototype of MAPK signaling. Mol Biotechnol 2005; 31: 151-174.

[53] RUPNIEWSKA Z, BOJARSKA-JUNAK A. Apoptoza: Przepuszczalność błony mitochondrialnej i rola pełniona przez białka z rodziny Bcl-2. Postepy Hig Med Dosw 2004; 58: 538-547.

[54] RUTZ M, MATZGER J, GELLERT T, LUPPA P, LIPFORD GB, WAGNER H, BAUER S. Toll-like receptor 9 binds single-stranded CpG-DNA in a sequence- and pH-dependent manner. Eur J Immunol 2004; 34: 2541-2550.

[55] SALVADOR JM, MITTELSTADT PR, BELOVA GI, FORNACE JR. AJ, ASHWELL JD. The autoimmune suppressor Gadd45alpha inhibits the $\mathrm{T}$ cell alternative p38 activation pathway. Nat Immunol 2005; 6: 396-402.

[56] SALVADOR JM, MITTELSTADT PR, GUSZCZYNSKI T. Alternative p38 activation pathway mediated by $\mathrm{T}$ cell receptor- proximal tyrosine kinases. Nat Immunol 2005; 10: 1038-1177.

[57] SALMOND RJ, FILBY A, QURESHI I, CASERTA S, ZAMOYSKA R.T-cell receptor proximal signaling via the Src-family kinases, Lck and Fyn, influences T-cell activation, differentiation, and tolerance. Immunol Rev 2009; 228: 9-22.

[58] SHIM JH, PASCHAL AE, BAILEY ST, RAO P, HYDEN MS, LEE KY, BUSSEY C, STECKEL M, TANAKA N, YAMAMDA G, AKIRA S, MATSUMOTO K, GHOSH S. TAK1, but not TAB1 or TAB2, plays an essential role in multiple signaling pathways in vivo. Genes Dev 2005; 19: 2668-2681.

[59] SINGH RAK, ZHANG JZ. Differential activation of ERK, p38, and JNK required for Th1 and Th2 deviation in myelin-reactive T cells induced by altered peptide ligand. J Immunol 2004; 173: 7299_ 7307.

[60] SUMBAYEV VV, YASINSKA M. Role of MAP kinase- dependent apoptotic pathway in innate immune responses and viral infection. Scand J Immunol 2006; 63: 391-400

[61] SWEET L, SCHOREY JS. Glycopeptidolipids from Mycobacterium avium promote macrophage activation in a TLR2-and MyD88- dependent manner. J Leuk Biol 2006; 80: 415-423.

[62] SYMONS A, BEINKE S, LEY SC. MAP kinase kinase kinases and innate immunity. Trends Immunol 2006; 27: 40-48.

[63] SZCZEPAŃSKI M, GÓRALSKI M, MOZER-LISEWSKA I, SAMARA H, ŻEROMSKI J. Rola receptorów Toll-podobnych w odporności. Post Biol Kom 2004; 31: 543-562

[64] TEDDY TC, YANG TTC, XIONG Q, GRAEF IA, CRABTREE GR, CHOW CW. Recruitment of the extracellular signal-regulated kinase/ribosomal S6 kinase signaling pathway to the NFATc4 transcription activation complex. Mol Cell Biol 2005; 25: 907-920.

[65] WESTRA J, van der MEER DB, de BORE P, van LEEUWEN MA, van RIJSWIJK MH, LIMBURG PC. Strong inhibition of TNF- $\alpha$ production and inhibition of IL- 8 and COX- 2 mRNA expression in monocyte-derived macrophages by RWJ 67657, a p38 mitogen-activated protein kinase (MAPK) inhibitor. Arthritis Res Ther 2004; 6: R384- R392.

[66] ZHANG K, ZHANG L, ZHU D, BAE D, NEL A, SAXON A. CD40-mediated p38 mitogen-activated protein kinase activation is required for immunoglobulin class switch recombination to IgE. J. Allergy Clin Immunol 2004; 110: 421-428. 
[67] ZHANG Y, DONG C. Regulatory mechanisms of mitogen-activated kinase signaling. Cell Mol Life Sci 2007; 64: 2771-2789.

[68] ZHONG XP, HAINEY EA, OLENCHOCK Ba, ZHAO H, TOPHAM MK, KORETZKY GA. Regulation of $\mathrm{T}$ cell receptor-induced activation of the Ras-ERK pathway by diacylglycerol kinase zeta. J Biol Chem 2002; 277: 31089-31098.

Corresponding author: Malgorzata Krzyzowska

Division of Immunology, Department of Pre-clinical Sciences, Faculty of Veterinary Medicine,

Warsaw University of Life Sciences

Ciszewskiego 8, 02-786 Warsaw

e-mail address: malgorzata_krzyzowska@sggw.pl 